\title{
Integrating Social Studies Education, Religion and Cultural Values for National Interest as Panacea for Curbing Social Violence in Nigeria
}

\section{A.A. Adediran and Lijadu M.O.}

Social Studies Department, School of Arts and Social Sciences, Federal College of Education, Abeokuta, Ogun State, Nigeria

Corresponding author: speaktoa3@yahoo.com

Received: 03 Jan., 2019

Revised: 22 Feb., 2020

Accepted: 27 March, 2020

\begin{abstract}
The experience of civil war that threatened the unity of this nation Nigeria would have been lessons for all citizens if the society would continue to be a united nation, but the recent spate of anti-social activities leading to outright social violence points to blank reminiscence of those gloomy days. New forms of social violence that are alien to our cultural and society are on the increase. Our unity, security, peace and survival as a nation are threatened. Yet there is an unpredictable expansion of our education sector and a prolific growth and development of religious groups which in the ordinary sense should be agents of peaceful co-existence. What then is wrong? This paper argues that there is a missing link between social studies education, cultural values, ethnicity, religious values and ideals. Ethnocentric interests are priced above national unity; religions highly politicized thereby leading to clash of ideologies and thus social violence. It is the opinion of these writers that since social studies education is both value free and value laden subject which cannot be out rightly separated from religious, cultural and political interest, a synthetic integration of the virtues of these institutions for national interest will be panacea for curbing social violence in Nigeria. The paper delves into the role of social studies education in eradicating or stemming all forms of social violence in Nigeria. The paper then recommends that National inter-ethnic and inter-religious conferences to be organized quarterly every year for values assimilation and orientation as a measure for curbing social violence.
\end{abstract}

Keywords: Violence, Religion, Social Studies, Integration, Curbing, National 
Nigeria is being strengthened by the unity and understanding of the exiting of different groups of people in the society. The unity of these of Nigeria a united nation since 1980 point to the end of unity and understanding tat exist in the society despite its heterogeneous cultural background. In spite of all these above explanations, that does not means that, Nigeria had been violence free, because Nigeria experienced a civil war that nearly tore Nigeria apart.

The rate of social violence according to Dienye (2012) in Nigeria society like suicide bombing, kidnapping, ban robbery, human trafficking, religious crises, ethnic clashes and may more resulting in insecurity of live and property threaten the unity and oneness and the continued existence of the society. It all the above explanation, Nigeria is not excluded from the ethical value crisis of the world prompted by corrupt practice, bad governance and poor leadership. It is not gain saying the fact that the Nigerian state is connected by high level moral decadence and collapse of ethical values in virtually all aspects of our lives.

The fact remains that Nigeria as a state among the international community is at across road interns of its cultural values in social, political religion, economic and educational parlance. This invariably is adversely affecting the developmental efforts and interpersonal relations. According Oyebode in Olayinka (2008) moral, cultural value a moral decadence in Nigeria is very often wrongly traced to a poor and ignorance followership that ever ready an wiling to hail the power that be, rather than tracing these wrong acts to leadership that determine and shape the society for better.

It is indication that the various institutions or society that facilitate socialization social change are in comprehensive in their apply to social violence this does not subscribe to in on the part of the agents, to rather indicate according to Dneye (2012) a missing link between social studies education, religion and cultural values in their bid to inculcate right types of values the people thereby leading to social violence.

\section{Social Violence}

Violence is a behavioral trait or act, generally intends or directed to inflict injury or pain on someone. According to World Health Organization (2002) violence involves the deliberate use of physical force or power against a person or a group or even a community. Such intentional use of brute force may result to very serious injury, psychological harm or even sudden death of the victim of violence. From the legal perspective, violence is generally regarded as a violation of many human rights such as the right of life, the right to liberty, the right to autonomy and security of persons, the right to equality and non-discrimination, the rights to be free from torture and cruel, in human and degrading treatment or punishment, the right to privacy and the right to the highest attainable standard of health, some violence according to Olateru-Olagbegi (2006) may be perpetrate in the form of mental violence as in the case of abuse, neglect or negligent treatment of orphans and the aged, maltreatment or exploitation of the innocence of a child and sexual abuse or even a wife starving her husband of food or sexual obligation (Krug 2002). 
The nature and conventional understanding of violence generally includes those acts which derive from a power relationship including threats and intimidation between junior and senior students in a boarding house for example. The use of power or brute force may also include neglect or some simple acts of omission, including the obvious violence acts of commission. In other words, the use of physical force will also mean the neglect and all types of physical, sexual and psychological abuse, as well as suicide and other self-abusive acts. The outcomes of these patterns of violence will according to Nwideeduh (2003) include psychological harm, deprivation and maldevelopment. There is a growing recognition that some form of violence may not necessarily result in injury or death, but however pose substantial burden on individuals, families, communities and health care systems. Indeed man forms of violence against women, children and the elderly occasionally can result in physical psychological and social problems that may not necessarily manifest in injury, disability or death. Some of them can even be immediate as well as delayed while others may linger or for several years after the initial abuse.

The above explanation indicated that, the nature of human society makes social violence inevitable. In modern societies violence may manifest in different terms. According to Ritzer in Dienye (2012) on social violence may not always take the form of overt physical cruelty. It can be hidden in more complex practices of exploitation and controls. The new Websters Dictionary of English language define violence as the use of physical force so as to damage or injury somebody or destiny something. It is an abusive use of force. Violence takes different forms and may manifest in different degrees. Dokun in Dienye (2012) identified four types of violence which include structural violence, terrorism, gender and environmental violence.

In a multi-cultural society like Nigerian where every group wants even representation and share of the national cake and in most cases according to Dnemye (2012) struggle for leadershership control, there is bound to be conflict leading to violent. This could be dues to denial of right, oppression, marginalization, exclusion, deprivation, corruption, cheating etc. Violence exist wherever one group control in its own interest the life chances, environments, audition and perception of another group (Ritzer, 2008).

\section{Religion}

By sacred thing, one must not understand simply those personal things which are called God or spirit, a rock, a tree, a spring, a pebble, a piece of wood, a huse in a word anything can be sacred. Durkheime in traniyu (2012), Haralambos and Holborn (2008) in an attempt do analyzing or decoding the above quotation from Emile Durkheime one can deduced that one way of defining religion it to see it in terms of functions of perform for society or individuals. An example of that approach is provided by yingerm Tiamiyu (2012) who defined religion as a system of beliefs and practices by means of which a group of people struggles with ultimate problems of human life quoted in (Hamition 1995). However, Hamition notes two main problems with such a definition first, of allows the inclusion of a wide variety of beliefs systems in the category religion, for instance by this definition communism could be regarded at a religion even throughout explicity rejects religious beliefs 
Secondly, it is based upon assumptions about the roles and purpose of religion. However these roles and purpose might vary between societies and should be the joy of sociology to uncover them by empirical investigation, not to assume what they are from the outset. Third phrases such the ultimate problems of human right are open to varied interpretations. Hamilton point outs that for some people, the ultimate problems of life might be 'simply hot to enjoy it as much possible, how to avoid pain and ensure pleasure, it is cleared that many other aspect of Social life, apart from religion, addresses such issues. For example medicine and leisure.

Duteheim in Tiamiyu (2012) defined religion in terms of distinction between sacred and the profane. Sacred object four example the cross in Christianity produce a sense of awe, veneration and respect, whereas profane object come always treated with respect. A common approach of a substancive definition of religion is to define it in terms of supernatural beliefs. Thus Roland is Tiamiyu cross starts that religion refers to the extreme of supernatural beings not have a governing effect on life.

According to Masih (2010), "religion is committement to a kind or quality of life that purports to recognize a source beyond itself... and those issues in recognizable fronts in human conduct (e.g. local maturity), culture and thought (e.g. philosophy). In Nigeria, there are different types of religious groups. No matter how many they may be the aim is to influence as their faithfully to hold unto their faith. In the morals of Masih (2010), religious acts assume moral earnestness where social salaries and individual feelings are equally matched and delicately balanced. He also emphasized alleviation of human suffering as a major conman of religion. Religion is more than just a form of worship between man and God but also in terms of the roles it is performing in the society. For example, Osoba (2007) asserted that religion gives people a way of understanding the world in which they live. It tells us what is night and what is evict what is just and unjust, virtue and vices etc. It feeds us spiritually and giving the nation comfort, security, love and hope.

\section{Social Studies Education}

Social studies Education can be defined in different ways according to situations, aspirations and expectation of the people. A very careful look at the analysis of the definition of social studies education in educational literature simply shows that social studies education as been defined in the following ways. Udoh in Alhassan (2013) express social study education as an integrative field of study which probes man's symbiotic relationships with his environment, endow man with the reflective or contemplative capacities, intellectual, affective, social and work skills to enable him understand his world and its problems, and to rationally solve or cope with them in a given society. Osakwe and Itedjare (1993) stated that social studies education is an integrated and interdisciplinary field of study whose ultimate aim is to produce people who are civically component.

Ololobou (1992) illustrated social studies education as a programme of study in which clients are exposed to carefully selected physical and social environment realities, with an in-built package for the development of skills of various kinds and nurturing of values, attitude and actions. Conducive to the continued orderly survival of the society. Social studies education is an integrated body of knowledge 
formulated to equip the learner with significant values, attitudes, skills and knowledge in order to be productively functional in the society. In acceptance, Imogie (1993) stressed that it is the responsibility of social studies education instruction to provide citizenship education to the young stars. Social studies education is a value laden instruction which relatives citizen obligations and duties to the states. It is a process of integrating the citizens with national policies, economics, social and technological values.

In America social studies is defined as citizenship education which appreciate one's culture and have a thorough knowledge of existing norms, structure, and privileges. In another development, Barths and Sharmis in Alhassan (2013) defined social studies as Synonymous with the social sciences. Relatively, Ogunsanya (1984) opined that social studies is a synthesis of relevant components of subjects in the social science such as economics, political science, sociology, anthropology, history, archaeology, geography, religion, pure and applied science, health education, which are integrated to form its concepts as well as promote easy adaptation to societal changes. Hence, Osakwe and Itedjare (1993) in their opinion noted that social studies is the interpretation of interrelationship of different subject aimed at inculcating national consciousness and national unity, imbibing the right types of values and attitudes for self and inculcating the necessary skills, abilities and competences for the individual and the larger society.

The role of social studies in curbing social violence in Nigeria could be better appreciated when one consider its objectives, content and methodology vis-a-vis the goals and objectives as derived from the National Educational as contained in the social studies curriculum framework. The aims and objectives of social studies in Nigeria as derived from the National Education philosophy are:

The inculcation of national consciousness and national unity.

The inculcation of the right type of values and attitudes for the survival of the individual and Nigerian society.

The training of the mind in the understanding of the world around and

The acquisition of appreciate skills, abilities and competences both mental and physical as equipment for the individual to live in and contribute to the development of his society (FGM, 2001) from the above, it is clear that these aims and objectives of social studies constitute essential conditions for curbing social violence and for the development and building of any nation. Indeed, as stated in the educational philosophy of Nigeria, all instruction in social studies is geared towards inculcating in the students the following values.

Faith in man's ability to make national decisions

Moral and spiritual values inter-personal and human relation.

Shared responsibility for the common good of society and

Promotion of the emotional physical and psychological health of all children (FRN, 2014) acquisition of these values and codes of conducts are necessary for the reduction of social vices in the society. The formidable task for curbing social violence in Nigeria certainly requires an 
informed and effective citizens, conscious effects are needed to produce such because citizens are make, not born. As a citizenship transmitter, social studies curriculum plays a significant role of educating the students in harmonious living and can inculcate demographic ideas and rational decision-making as an effective students.

\section{Cultural Values}

Cultural values like customs, beliefs system, kinship relationships, social norms and tradition defines the nature of interpersonal relationships in society and by consequence, the stability of such society. On the information and communication processes, traditions and other behavioural norms influence people communication patterns, how to communicate and the way and manner one should do it depends on traditional of that society, but this has changed because of modern communication systems that abound everywhere in the society. The traditional cultural values have been eroded, therefore people do things the way they feel is better.

Fukuyama (2005) sees cultural values as the informal shared values, norms and behaviours that characterize human societies. Thompson (2001) describe cultural values as the total complex pattern of customary human behaviour, social forms and material traits embodied in thought, speech, action, and artifacts and dependent upon the human capacity for learning and transmitting knowledge, and system of abstract thought. To him, the elements of cultural values include beliefs, morals, laws, customs, opinions, religions, superstitions and art of the people in a society. Cultural values in Nigeria are loaded that is people exhibit behaviours and attitudes such as honesty, social justice, fairness, faithfulness, discipline etc, whether in the family unit or within the large society. Cultural value is essential for an effective and stable political administrative authority as well as efficient social and economic structures. Unfortunately however, the Nigerian society today is plagued by problems of unethical conduct both government and among the larger society. Basic traditional values cherished in our society have now been lost and a state of moral decadence now pervades the entire country, indicating that urgent steps need to be taken to address the issues.

\section{Curbing Social Violence Through Social Studies, Education, Religion and Cultural Values}

Social studies education is a societal subject, a problem solving subject, an integrated subject that has integrate all the social sciences subjects to form aholistic subject, that is why social studies is very critical to human survival, development and sustenance of human society. (Maduagu, 1998). Social studies cannot be separated from ethnic-cultural values and religion practices prevalent in a society. Western education according to Dienye (2012) cannot be removed christianity in totality. This is due to the traditional antecedent that gave birth to it. In the same vein, there is need for peaceful co-existence, integration of the salient values and ideals of ethnic relations, politics, religion and social studies education in order to curb violence in the society.

Gele and Philip-Ogoh (2013) stress that social studies education is a subject that is society oriented 
which helps citizens to live, interact and interrelate thereby hammering for harmonious living among people in any society. This has made social studies education according to Dienye (2004) as a training field where individuals in society are trained to fit into various fields of endeavours in other institutions of society. The other institutions include religion, politics, economic institutions to mention a few. In the same vein, Dokun (2005) stated that there is tendency to celebrate the ideal of violence free in all religious, this can also be extended to the ethnic groups where there is dire need for the survival of the society beyond an individual life span. Every political group should seek to influence the followership through mutual understanding, relationship and promise of security and peace. If all these essential institution of human society covet such lofty virtues and propagate the same, our society shall soon get rid of violence.

Inter dependency is the hall mark of the continuity of human race, if the above statement valid therefore no society should pride her cultural value above the culture values in other societies. In the same vein, ethnic group or other religions sect/or groups within a society should see their survival as necessitated by other ethnic groups or religious groups. This will curb religious and political violence leading to social violence and thus ethnic sentiment. When ethnic values are above national values, ethnocentric interest will prevail, this may result in social violence. That is why social studies education and religious should be upheld in the society in order to see to the total eradication of social violence in the society so as to give way for harmonious living for the prevalence of national interest.

\section{CONCLUSION}

There are certain needs human being cherish that can never be denied and which must be satisfied for individual development and for the social behaviour. These needs may include civil, religious, political, education, society and right to liberty among others. In the same way, social groups and in a wider range, ethic groups have collective needs which may settle some issues in social life. A distortion of such needs may lead to conflict and consequently violence. This paper has tried to $\mathrm{x}$-rayed various ways by which violence can be ensued, it has also discussed different types of violence and how these violence can affect human life and properties. The paper therefore concluded that social studies education as a problem solving subject and religion if properly handle and uphold in a positive ways can help to solve or curb social violence. Cultural values should also be recognized and cherished to survival of the society that has been full of vices. The ideas, values and knowledge of these subjects can help to curb social violence for peaceful co-existence in the society.

\section{Recommendations}

In view of the need for inter institutional solidarity for national peace and unity, the following recommendations are made for curbing social violence in Nigeria. They include:

1. Government should encourage and organize inter-religious and inter-ethnic conferences quarterly in every year. This will promote peace through values assimilation and orientations. 
2. Religious leaders should detach themselves from active political participation and concentrate on their religious roles. This will save them from being influenced by political leaders in their bid to cling onto power.

3. Proper sanctions should be melted out to ethnic groups found to have any link with social violence of any kind. This could be in form of government denying them of their monthly allocation from federal government to the state or local government. This may create fear in the hands of their leaders of the ethnic or regional groups thereby leading to peace.

4. Help check on extremist clerics who use volatile sermons.

5. The teaching of social studies in schools should be the prerogative of the trained social studies specialists.

6. Parents should inculcate cultural values unto their children.

\section{REFERENCES}

1. Adediran, A.A. 2014. Essential themes in social change for student in tertiary institution, Abeokuta. Beloved print.

2. Alhassan, E. 2013. The place of social studies education in curbing terrorism and militarism in Nigeria. Nigerian journal of social studies and civic education, 5(1): 228 - 239.

3. Dienye, V.U. 2012. Integrating educational, religious, political and ethnic values for national interest: A strategy for curbing social violence in Nigeria. A paper presented at $6^{\text {th }}$ Annual conference of association of sociologists of education of Nigeria (ASEM), 2012.

4. Dokun, O.O.P. 2005. Conflict and context of conflicts resolution. Ile-ife. Obafemi Awolowo University Press Ltd.

5. FGN. 2001. The national policy on education. Lagos. Federal government press.

6. FRM. 2004. "The national policy of education $4^{\text {th }}$ edition, Lagos; NERDC Press.

7. Fukuyama, F. 2000. Culture and economics development: Cultural concerns: international encyclopaedia of the social and behavioural sciences. Elsevier Science Ltd.

8. Gele, S.A.M. and Philip-Ogoh, A. 2013. Eradicating terrorism and militarism in Nigeria: A challenge for social studies teachers. Nigerian journal of social studies and civic education, 5(1): 290-307.

9. Imogie, I. 1993. Application of integration concept of social studies in Adaralegbe. A(ed) integration and innovation in Nigeria education. Lagos. Jas Publishers in association with the Nigerian academy of education.

10. Maduagwu, S.N. 1998. Educational management in Nigeria: Concepts and issues, Nigeria: Freshery printers and publishers.

11. Nwideeduh, S.B. 2003. The menace of cultism in Nigerian universities. in Nwideeduh, S.B. (eds) trends and issues in managing universities in Nigeria. Spring field publishers ltd.

12. Ogunsanya, M. 1984. Introduction to methodologies of social studies. Ibadan. Evans brothers limited. 
13. Olayinka, T.S. 2000. Ethic, value and moral decadence among Nigerians: social studies education as an agent of stabilization in Adekunle Adebayo (ed) ethical values and the challenges for national development in Nigeria. Ijebu Ode. Lucky Odoni Enterprises.

14. Ololobuo, Y.P.S. 1992. Preparing the social studies teachers in Nigeria. Journal of social studies, 1: 1-6.

15. Osakwe, E.O. and Itedjare, P. 1993. Social studies for tertiary students in Nigeria. Enugu. New Age publisher.

16. Osoba, A.J. 2007. "Religion and the future Nigerian: Christian view point in B.R Ismalia, D.Y. Akinyemi et al. the future Nigeria Vol. II Oyo: Odumatt press.

17. Oyebode, A. 2008. Re-thinking Nigeria social ethical values. Paper presented at the $1^{\text {st }}$ national conference of the school of arts and social sciences. Micheal Otedola College of primary education, Noforija, Epe, July 14-17.

18. Tiamiyu O. 2012. Societal violence and its implication on national security. A paper presented at $6^{\text {th }}$ Annual conference of association of sociologists of education of Nigeria (ASEM), 2012. 
